\section{Response to: 'Could abatacept directly target expanded plasmablasts in IgG4-related disease?' by Alegria et al}

We thank Alegria et $a l^{1}$ for their response to our letter. ${ }^{2}$ IgG4-related disease (IgG4-RD) is a chronic fibroinflammatory disorder that can involve various organs, but its origin remains unknown. ${ }^{3}$ Although elevated levels of circulating plasmablasts are observed in the active phase of IgG4-RD ${ }^{4}$ the pathogenesis cannot be fully explained by plasmablasts alone. In our report, ${ }^{2}$ we described a patient treated with abatacept who presented with complete depletion of circulating $\mathrm{CD} 19^{+}$cells at the secondary failure of rituximab. Because the serum levels of IgG4 decreased suddenly, the circulating plasmablasts and tissue resident plasma cells might also have decreased (figure 1). Despite this condition, the patient relapsed. It is important to identify the mechanism of the secondary failure of rituximab in this patient, and we consider that $\mathrm{T}$ cells play an important role in the pathogenesis of IgG4-RD.

As previously described, we did not know the specific reason why abatacept was effective in this patient because there was no expression of CD28 in the biopsy specimens. It is possible that follicular helper $\mathrm{T}$ cells are decreased by abatacept. ${ }^{2}$ Alternatively, abatacept may make dendritic cells and macrophages secrete indoleamine 2,3-deoxygenase, which can inhibit the proliferation of T cells. ${ }^{6}$ As Alegria et al noted, there is of course the possibility that abatacept affects both $\mathrm{CD} 19^{+} \mathrm{B}$ cells and $\mathrm{CD} 19^{+} \mathrm{CD} 38^{\text {high }}$ plasmablasts. It was recently reported that abatacept is effective for systemic lupus erythematosus (SLE). ${ }^{7}$ Elevated levels of plasmablasts, which have a population, that is, different from IgG4-RD, are observed in SLE. ${ }^{8}$ Understanding how abatacept works in SLE may be a reference for understanding why it was effective in this patient.

This patient has now successfully completed a 17 th administration of abatacept without any adverse effects, and her condition is very good. Although her serum levels of IgG4 initially continued to decline, they have recently remained around $200 \mathrm{mg} / \mathrm{dL}$. We consider that maintenance treatment is needed even when administering abatacept.

It is important to both identify the reasons for the efficacy of abatacept in IgG4-RD and verify the clinical efficacy of abatacept in IgG4-RD.
Motohisa Yamamoto, ${ }^{1}$ Hiroki Takahashi, ${ }^{1}$ Kenichi Takano, ${ }^{2}$ Tetsuo Himi, ${ }^{2}$ Hiroshi Nakase ${ }^{3}$

${ }^{1}$ Department of Rheumatology, Sapporo Medical University School of Medicine, Sapporo, Japan

${ }^{2}$ Department of Otolaryngology, Sapporo Medical University School of Medicine, Sapporo, Japan

${ }^{3}$ Department of Gastroenterology, Sapporo Medical University School of Medicine, Sapporo, Japan

Correspondence to Dr Motohisa Yamamoto, Department of Rheumatology, Sapporo Medical University School of Medicine, South 1-West 16, Chuo-ku, Sapporo, Hokkaido 060-8543, Japan; mocha@cocoa.plala.or.jp

Competing interests None declared.

Provenance and peer review Commissioned; internally peer reviewed.

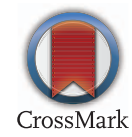

To cite Yamamoto M, Takahashi H, Takano K, et al. Ann Rheum Dis 2016;75:e74. Accepted 26 August 2016

Published Online First 20 September 2016

\section{G Linked}

http://dx.doi.org/10.1136/annrheumdis-2016-210400

Ann Rheum Dis 2016;75:e74. doi:10.1136/annrheumdis-2016-210403

\section{REFERENCES}

1 Alegria GC, Pochard P, Pers JO, et al. Could abatacept directly target expanded plasmablasts in IgG4-related disease? Ann Rheum Dis 2016;75:e73.

2 Yamamoto $\mathrm{M}$, Takahashi $\mathrm{H}$, Takano $\mathrm{K}$, et al. Efficacy of abatacept for IgG4-related disease over 8 months. Ann Rheum Dis 2016;75:1576-8.

3 Yamamoto M, Takahashi H, Shinomura Y. Mechanisms and assessment of IgG4-related disease: lessons for the rheumatologist. Nat Rev Rheumatol 2014;10:148-59.

4 Wallace ZS, Mattoo H, Carruthers M, et al. Plasmablasts as a biomarker for IgG4-related disease, independent of serum IgG4 concentrations. Ann Rheum Dis 2015;74:190-5.

5 Fox RI, Fox CM. IgG4 levels and plasmablasts as a marker for IgG4-related disease (IgG4-RD). Ann Rheum Dis 2015;74:1-3.

6 Davis PM, Nadler SG, Stetsko DK, et al. Abatacept modulates human dendritic cell-stimulated T-cell proliferation and effector function independent of IDO induction. Clin Immunol 2008;126:38-47.

7 Danion F, Rosine N, Belkhir R, et al. Efficacy of abatacept in systemic lupus erythematosus: a retrospective analysis of 11 patients with refractory disease. Lupus 2016. Published Online First: 24 Mar 2016. doi:10.1177/0961203316640911

8 Koarada S, Tashiro S, Tokuda Y, et al. Persistent expression of CXCR5 on plasmablasts in IgG4-related disease. Ann Rheum Dis 2015;74:e32.
Figure 1 Clinical course of a patient treated with abatacept. Complete depletion of circulating $\mathrm{CD} 19^{+}$cells was observed at the secondary failure of rituximab. No relapse has been observed after switching from rituximab to abatacept. ABT, abatacept; RTX, rituximab.

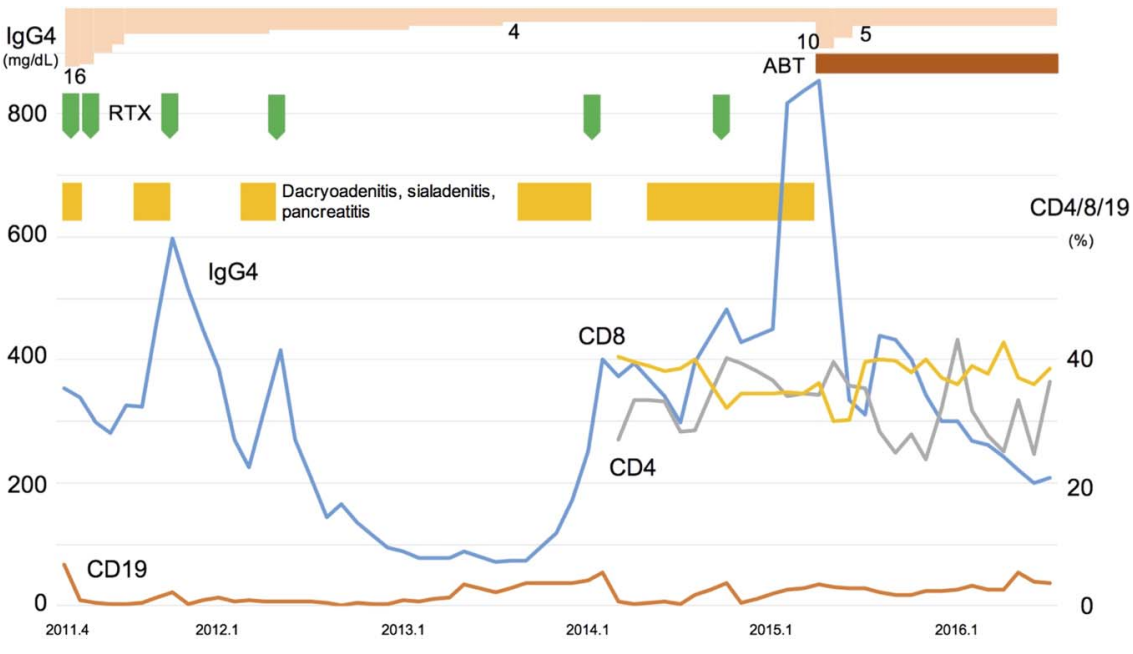

